\title{
Correction to: Solution procedures for block selection and sequencing in flat-bedded potash underground mines
}

\author{
Cinna Seifi ${ }^{1}$. Marco Schulze ${ }^{2} \cdot$ Jürgen Zimmermann ${ }^{1}$
}

Published online: 13 April 2021

(c) The Author(s) 2021

\section{Correction to: OR Spectrum https://doi.org/10.1007/s00291-021-00618-z}

Unfortunately in the original version of the article the information of the second author Mr. Marco Schulze was published incorrectly.

Previously read as

Clausthal University of Technology, 34131 Kassel, Germany

It should read as

K+S Aktiengesellschaft, 34131 Kassel, Germany

In Constraint (16) (on the 13th-page), there is some space before $\forall b \in \mathcal{B}: x_{b t} \in\{0,1\} \quad \forall b \in \mathcal{B}, \forall t \in \mathcal{T}$

The original article has been corrected.

Open Access This article is licensed under a Creative Commons Attribution 4.0 International License, which permits use, sharing, adaptation, distribution and reproduction in any medium or format, as long as you give appropriate credit to the original author(s) and the source, provide a link to the Creative Commons licence, and indicate if changes were made. The images or other third party material in this article are included in the article's Creative Commons licence, unless indicated otherwise in a credit line to the material. If material is not included in the article's Creative Commons licence and your intended use is not permitted by statutory regulation or exceeds the permitted use, you will need to obtain permission directly from the copyright holder. To view a copy of this licence, visit http://creativecommons.org/ licenses/by/4.0/.

The original article can be found online at https://doi.org/10.1007/s00291-021-00618-z.

Cinna Seifi

cinna.seifi@tu-clausthal.de

1 Institute of Management and Economics, Operations Research Group, Clausthal University of Technology, 38678 Clausthal-Zellerfeld, Germany

$2 \mathrm{~K}+\mathrm{S}$ Aktiengesellschaft, 34131 Kassel, Germany 